\title{
Corruption and Its Effects on Sustainable Economic Performance
}

\author{
Michael Appiah" \\ School of Management Science \& Engineering \\ Department of Finance \& Economics \\ Jiangsu University, China.

\section{Derrick Yaw Idan Frowne} \\ Department of Accounting \\ University of Cape Coast, Ghana. \\ Anita Idan Frowne \\ Department of Human Resource Management \\ African University College of Communication, Ghana.
}

\#Corresponding Author

\begin{abstract}
The study examines corruption and its effects on achieving sustainable economic performance in Africa with a data set from 2002-2017. The Hausman Test for determining the appropriate model selection between Random and Fixed effects was employed with the fixed effects model of estimation chosen to be the appropriate method of estimation indicating that the degree of relationship and significant between corruption and sustainable economic performance in negative. The $\mathrm{R}^{2}$ explains that $95 \%$ of variations in sustainable economic performance in the estimation of prime independent variables. Aside corruption having a negative and insignificant impact on sustainable economic performance, an increase in human development and labour resulted in a positive and significant relations on sustainable economic performance, with the rest of the explanatory variables having a poor and negative affiliation with sustainable economic performance. The above therefore follows the empirical, conventional and theoretical perspective that corruption declines growth and sustainability both domestically and globally.
\end{abstract}

Keywords: Corruption, Economic Performance, Random Effects, Fixed Effects, West Africa 


\section{INTRODUCTION}

Corruption is a concept with numerous countenances. It is portrayed by a scope of economic, political, administrative, social and cultural factors, both domestic and worldwide in nature. Corruption isn't an intrinsic type of conduct, but instead a side effect of more extensive elements. It results from connections, opportunities, strengths, and weaknesses in socio-political frameworks. It opens up and shuts down spaces for people, gatherings, associations, and organizations that populate common society, the state, the public part, and the private area. It is, most importantly, the aftereffect of dynamic connections between multiple performers (Menocal et al., 2015).

Corruption has been distinguished as a standout amongst the most weakening issues in the developing world. Nonetheless, while the impact of corruption is borne by the constituents of a corrupt state, in an inexorably reliant world, the expense is effectively spread to different nations, particularly with the more conspicuous pretended by multilateral and bilateral accomplices that give remote help to creating economies. It has been seen that some remote guide programs have a low-level selectivity against exceptionally corrupt governments (Alesina \& Weder, 2002).

Consequently, in a roundabout way, the expense of bribery, kickback, and blackmail in developing countries are additionally borne by beneficiary states, yet additionally by contributors. As exchange cost increment and venture costs, expand in beneficiary states, development help gave to powerless states are misallocated and livelihoods redistributed from target recipients to different beneficiaries, in this manner diminishing the productivity and viability of givers and squandering the charges of individuals from contributor states (Easterly, 2002). From this time forward, look into a hostile to defilement measures ought to get ceaseless consideration for accomplishing economic development and social equity with regards to developing economic reliance.

The objective of the study is to look at corruption and its effects on sustainable economic performance. This research paper is structured as follows: The afterward section of this research paper will briefly deal with some related literature on corruption and its effects, discuss the definition of corruption, indicating out some concerns on Africa. The third section discusses the data, model specification, methodology and the analysis of the data. The fourth section deliberates the empirical findings and results of corruption, and the last section talks about the conclusion and policy implication.

\subsection{LITERATURE REVIEW}

There has been enormous literature and studies on corruption and its effects on the society and economy. Some authors and researchers are of the view that corruption increases and enhances economic growth, thus there is a positive relationship and significant between corruption and economic growth. On the contrary, other authors and studies are also of the opinion that corruption is both socially and economically detrimental and thus the relationship that exists between corruption and economic growth is always negative. 
Authors and studies who are of the view that corruption has a positive and significant relation to economic growth include Leff (1964) who sees corruption as "grease money" to loosen the squeaky helms of an inflexible administration". Also, Huntington (1968) pointed out that for speedy and efficiency at work, then corruption is what is needed to be practiced. Again, Friedrich (1972)maintained that signs of corruption are mostly positive when it comes to speeding up processes and finally Nye (1967)claimed that corruption eases economic growth and investment, thus, corruption rises efficiency in an economy.

On the other side of the coin, most authors also believed and tested that corruption declines, growth and its morally wrong to be corrupt or corrupted. Mauro (1995) in his study on "Corruption and Growth" came out with the view that corruption is found to bring down investment, subsequently bringing down economic growth. Vinod (1999)evaluated that an act of corruption worth $\$ 1$ inflicts a $\$ 1.67$ liability on the economy. Tanzi and Davoodi (1998)indicated that corruption reduces growth by decreasing government revenue necessary to finance industrious spending. Again, Abed and Davoodi (2000)locate a negative affiliation between genuine GDP per capita growth and corruption. Mo (2001) examines the connection between corruption and economic growth (GDP Growth) and his exact investigation uncovers that a 1 percent increment in the corruption level decreases the growth by about 0.72 percent. He continued to record that most significant medium through which corruption impact growth in the economy is political instability, which explains for almost $53 \%$ of the total outcome.

Again, Habib and Zurawicki (2001) recorded that his outcomes support the negative impacts of corruption on investments. He additionally features a vital thus far neglected qualification: the effect of corruption on local direct investments is significantly more fragile than the effect on its foreign counterpart. Corruption has been an economic activity that requires some political means. Exertion dedicated to the aggregation of this sort of learning has an elective use in human capital creation. Corruption diminishes economic growth through a negative impact on investments in human capital (Del Monte \& Papagni, 2001). In a study by Blackburn, Bose, Haque, and Control (2006) recorded that corruption emerges from the motivating forces of public and private organizations to plan in the disguise of data from the government. Later they continued to indicate the motivating forces rely upon total economic activity which, thus, relies upon the rate of corruption. Their model produced numerous advancement routines, change between which may or on the other hand may not happen. It was then confirmed that the connection between corruption and development is anticipated to be negative.

\subsection{AFRICA IN CORRUPTION}

Corruption and prostitution have always been seen to be at the same level endangering individual morals of a person and the country as a whole(Campos \& Pradhan, 2007). The major problem and challenge of humanity and the world now is corruption. It has been increasingly seen as a threat to the existence of the human race to some extent that it is termed "crime against humanity" by some social commentators (Bantekas, 2006). The main obstacle to the attainment of sustainable development goals and good 
governance attribute to the existence of corruption which have a detrimental effect on the social, political and economic well-being of societies and cultures (Lumumba \& net, 2014). The Commission for Africa has identified corruption as a major concern which affects development and governance negatively (Molyneux, Hotez, \& Fenwick, 2005).

For development, growth, and governance, Africa lag behind other regions of the world with the situation summarized as whiles there are increases in human development indicators, Africa was always at the bottom and at the same level (MUKANDALA, FOX, \& LIEBENTHAL, 2006). There has been a stagnation in development and growth with most of the population living under the poverty line of $\$ 1$ per day (Rwekaza, 2000).

The issue of corruption cannot be seen exclusively as an Africa issue. It is imported, sustained, created and settled in Africa continent. Accordingly, while corruption is a worldwide challenge, its belongings are progressively shown in Africa and other developing nations. Corruption has 'unseated' governments in Brazil, Italy, Ecuador also, India and prompted a coup d'état in Thailand in 2006(Lash \& Batavia, 2013). Consequently, it has been acknowledged by partners in the governance procedure that the expense of corruption is malevolent and that no society can endure its grasp.

\subsection{DATA}

The data used in this study consist of annual observations on control of corruption as the variable of interest. The Control of corruption Index spans from -2.5 to 2.5, with positive numbers representing lower levels of corruption, as a proportion of a nation's sustainable economic performance the study utilizes the gross domestic product measured in current U.S. dollars as the dependent variable, capital (proxied by gross capital formation \% of GDP), human development proxied by human development index, inflation proxied by consumer price index labor, and trade openness measured in \% of GDP used as explanatory variables for all 16 West African countries. The data on sustainable economic performance, capital, labor, inflation, and trade openness were sourced from the World Bank's Development Indicators 2018, data on the Human Development Index was taken from UNDP (2018). The data covers the period 2002 through to 2017 for an individual country, these periods were chosen as a result of the unavailability of corruption data for the countries under study.in view of this, the data on control of corruption has a starting year period from 2002. The data on control of corruption were sourced from the World Governance Indicators from the World Bank Development Indicators.

\subsection{MODEL SPECIFICATION}

The model developed in this paper looks to catch the circumstance of developing countries where corruption plays an important role in the economic system. For crosssection estimation, the time range of the variables under estimation ought to be the same. In this study, the time range of all the variables is equal from $2002-2017$. The study seeks to investigate corruption and its effects on sustainable performance, thus it seeks to estimate the correlation between corruption and sustainable economic performance. This can be estimated by a regression equation which is consistent writers on the issue of corruption. 
Where GDP is Sustainable Economic Performance, CAP is Capital formation, COC is Control of Corruption, HDI is the Human Development Index, INF as Inflation, labor is a Labor and trade is trade openness. An econometric equation is developed from above

$$
\begin{gathered}
\text { GDPit }=\mathrm{a}+\beta_{1} \mathrm{CAPit}+\beta_{2} \mathrm{COCit}+\beta_{3} \mathrm{HDIit}+\beta_{4} \mathrm{INFit}+\beta_{5} \mathrm{LABit}+ \\
\beta_{6} \text { TRADEit }+ \text { eit } \ldots \ldots .(2)
\end{gathered}
$$

Where indicate the 16 countries under study, it denotes the time series, a is the intercept with

$\beta_{1}, \beta_{2}, \beta_{3}, \beta_{4}, \beta_{5}$, and $\beta_{6}$ are the coefficients to be estimated in the study.

\subsection{METHODOLOGY AND ANALYSIS OF DATA}

Different meanings of corruption and its relations with economic growth as observed in many studies have demonstrated that corruption does the wrong thing rather than the beneficial thing. This is in accordance with the general saying that wrong thing can't bring a beneficial thing, rather it will finish up bring a terrible thing, henceforth the effect of corruption is thought to be profoundly negative in most writings while some authors are of the feeling that corruption positively corresponds with economic growth.

In view of the above mentioned and the idea of this study, the examination utilizes straightforward econometric models like I'm, Pesaran and Shin test for unit root to check the stationarity, Random and Fixed effects models for regression, Hausman test to determine the appropriate model to use, and a further diagnostic test Pesaran CSD test to estimate the cross-section dependence among the variables to investigate corruption and its effects on sustainable economic performance.

\begin{tabular}{|c|c|c|c|c|c|c|c|}
\hline & GDP & CAP & $\mathrm{COC}$ & HDI & INF & $\mathrm{LAB}$ & TRADE \\
\hline Mean & $3.05 \mathrm{E}+10$ & 23.32352 & -0.640492 & 0.442022 & 101.1479 & 6922471. & 74.77081 \\
\hline Median & $90 \mathrm{E}+09$ & 21.64610 & -0.687382 & 0.435000 & 100.0 & 0. & 66.65085 \\
\hline Maximum & $70 \mathrm{E}+11$ & 73.77740 & 0.949543 & .654000 & 232.2560 & 59000000 & 311.3540 \\
\hline Minimum & 130630 & 4.703720 & -1.562250 & 0.263000 & 32.14930 & 183003.0 & 20.72250 \\
\hline Std. Dev. & $8.98 \mathrm{E}+10$ & 10.66285 & 0.492927 & 0.076349 & 29.9 & 1158 & 38.22759 \\
\hline Skewness & 4.192141 & 1.485542 & 1.231075 & 0.477750 & 1.390896 & 3.264057 & 3.135486 \\
\hline Kurto & 20.19005 & 6.211897 & 5.122006 & 3.668614 & 7.092173 & 12.74052 & 17.87751 \\
\hline Jarq & 3536 & 185.0 & 102 & 13.14691 & 236. & 1329 & 2519.765 \\
\hline Probability & 0.000000 & 0.000000 & 0.000000 & 0.001397 & 0.000000 & 0.000000 & 0.000000 \\
\hline Sum & $7.07 \mathrm{E}+12$ & 5411.056 & -148.5942 & 102.5490 & 23466.32 & $1.61 \mathrm{E}+09$ & 17346.83 \\
\hline Dev. & $1.86 \mathrm{E}+24$ & 26263.88 & 56.12776 & 1.346521 & 207174.1 & $3.10 \mathrm{E}+16$ & 337571.6 \\
\hline Observati & 232 & 232 & 232 & 232 & 232 & 232 & 232 \\
\hline
\end{tabular}

Table 1: Descriptive statistics 
Table 1 above gives a descriptive statistic on the variables by estimating the mean, median including measurements like standard deviation, with the highest and lowest mean being 6922471 and -0.640492 respectively. Skewness measures the point of symmetry and kurtosis point of peakedness of observations. The outcomes on skewness suggest that the data are positively and highly skewed with kurtosis suggesting a high peakedness.

As a matter of first importance, there was a careful report on the relationship and strength among the variables being utilized. A Pearson correlation Analysis was utilized to assess this model. Correlation is a method for researching the relationship between two quantities, persistent variables, for instance, age and health. Pearson's correlation coefficient ( $\mathrm{r}$ ) is a proportion of the quality of the relationship between the two variables (Pearson, 1895)

Table 2: Correlation and significance Matrix

\begin{tabular}{|c|c|c|c|c|c|c|c|}
\hline Probability & GDP & CAP & $\mathrm{COC}$ & HDI & INF & $\mathrm{LAB}$ & TRADE \\
\hline \multirow[t]{2}{*}{ GDP } & 1.000000 & & & & & & \\
\hline & ---- & & & & & & \\
\hline \multirow[t]{2}{*}{ CAP } & -0.133384 & 1.000000 & & & & & \\
\hline & $0.0424 * *$ & ----- & & & & & \\
\hline \multirow[t]{2}{*}{$\mathrm{COC}$} & -0.215108 & 0.368071 & 1.000000 & & & & \\
\hline & $0.0010 * * *$ & $0.0000 * * *$ & ----- & & & & \\
\hline \multirow[t]{2}{*}{ HDI } & 0.233931 & 0.277502 & 0.468915 & 1.000000 & & & \\
\hline & $0.0003^{* * *}$ & $0.0000 * * *$ & $0.0000 * * *$ & ---- & & & \\
\hline \multirow[t]{2}{*}{ INF } & 0.218514 & 0.188093 & 0.009055 & 0.305223 & 1.000000 & & \\
\hline & $0.0008 * * *$ & $0.0040 * * *$ & 0.8909 & $0.0000 * * *$ & ---- & & \\
\hline \multirow[t]{2}{*}{ LAB } & 0.943621 & -0.114158 & -0.221709 & 0.187910 & 0.154928 & 1.000000 & \\
\hline & $0.0000 * * *$ & 0.0827 & $0.0007 * * *$ & $0.0041 * * *$ & $0.0182 * *$ & ---- & \\
\hline \multirow[t]{2}{*}{ TRADE } & -0.265831 & 0.235829 & 0.054705 & 0.154053 & -0.007794 & -0.318184 & 1.000000 \\
\hline & $0.0000 * * *$ & $0.0003 * * *$ & 0.4069 & $0.0189 * *$ & 0.9060 & $0.0000 * * *$ & ----- \\
\hline
\end{tabular}

NB: *** Significant at the $1 \%$ level, ** Significant at the $5 \%$ level, * Significant at the $10 \%$ level.

Source: Author Computation, 2019 (Eviews9)

Results in the main section of Table 2 are from the Pearson Correlation and significance which included variables that are included in investigating corruption and its effects on sustainable economic performance. It can be noted from the above that HDI, INF, and labor have a positive correlation and significant at the $5 \%$ level. Besides, CAP, COC, and trade had a strong but negative correlation with the 
dependent variable and also significant at the $5 \%$ level. The figure below depicts line graphs showing changes between the variables.

Figure 1: Line graphs showing changes between the variables.

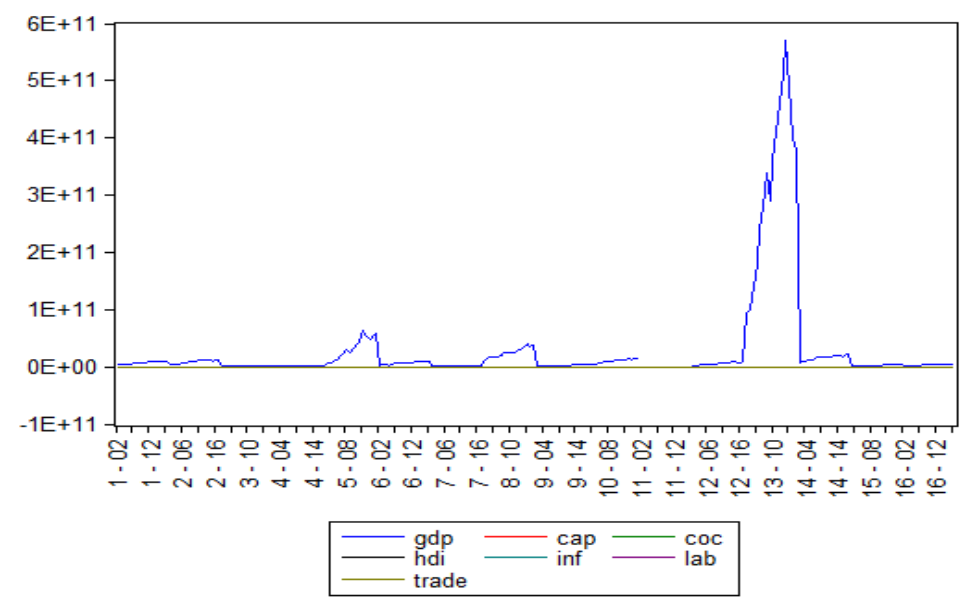

Source: Authors own, 2019.

\subsection{EMPIRICAL FINDINGS AND RESULTS}

\subsection{Unit root test}

The Im, Pesaran, and Shin test were employed to examine the stationarity or the presence of unit roots among the data. The Automatic lag selection criterion was used and SIC criterion was selected by an automatic lag selection.

Table 3: Unit Root Matrix

\begin{tabular}{|l|l|l|l|l|}
\hline $\begin{array}{l}\text { Im, } \\
\text { Pesaran, } \\
\text { and Shin }\end{array}$ & \multicolumn{3}{|c|}{ Level Individual Intercept } & \multicolumn{2}{l|}{$1^{\text {st }}$ Difference Individual Intercept } \\
\hline Variable & Statistic & Prob.** & Statistic & Prob.** \\
\hline GDP & 1.28011 & 0.8997 & -8.76258 & $0.0000^{* * *}$ \\
\hline CAP & -2.16201 & $0.0153^{* *}$ & -8.68055 & $0.0000^{* * *}$ \\
\hline COC & -2.10248 & $0.0178^{* *}$ & -8.58900 & $0.0000^{* * *}$ \\
\hline HDI & 1.41878 & 0.9220 & -8.07876 & $0.0000^{* * *}$ \\
\hline INF & 6.65545 & 1.0000 & -2.74979 & $0.0030^{* * *}$ \\
\hline LAB & 14.2746 & 1.0000 & -8.85459 & $0.0000^{* * *}$ \\
\hline TRADE & -0.48271 & 0.3147 & -9.92195 & $0.0000^{* * *}$ \\
\hline
\end{tabular}

NB: *** Significant at the $1 \%$ level, ** Significant at the $5 \%$ level, * Significant at the 10\% level.

Source: Author Computation, 2019(Eviews9) 
The empirical examinations on unit root assessment above show that control of corruption and sustainable economic performance proxy by GDP and other explanatory variables are stationary (no unit) of order one. They are stationary of similar order; 1(1). From the above results, it was established that Im, Pesaran and Shin test with individual intercept showed that time series are stationary of a similar order. The linear grouping of series data of similar order is said to be stationary. The level of series data shows the time series data have to be differences over their stationarity is reached.

\subsection{Hausman Specification Test}

The Hausman test will be affected to check the appropriateness of model selection for this study. This test is really to gauge the presence of a conceivable connection between the individual effects and the independent variables.

Table 4: Hausman Specification Test Results

Chi-Sq.

Test Summary $\quad$ Statistic Chi-Sq. d.f. Prob.

Cross-section random

101.043196

6

0.0000

Source: Author Computation, 2019(Eviews9)

From the above table 4 , it tends to be noticed that there is a probability value of 0.0000 showing a significant value at a significant dimension of $1 \%$. The estimation tosses out the nearness of a connection between the individual effects and the independent variables at the $1 \%$ level. Hence the null hypothesis of the Random-effect model is appropriate is rejected and the alternate hypothesis of the Fixed effects model is appropriate is accepted to mean the investigation is going to be estimated with the use of the fixed effects model.

\subsection{Fixed and Random Effects model estimations}

For the regression estimations suitable for this study, both random and fixed effects model was estimated to find corruption and its effects on sustainable economic performance. Both methods were used because, the fixed effects model will deliver unbiased appraisals of $\beta$, yet those assessments can be liable to high sample-to-simple variability. The random effects model will, with the exception of uncommon conditions, present bias in assessments of $\beta$, yet can incredibly oblige the fluctuation of those estimates leading to gauges that are nearer, on average, to the genuine value in a specific sample.

Diverse researchers may have distinctive inclinations for treading off predisposition and variance as such. More to the point, the quality of derivations about $\beta$ under either model can be objectively analyzed dependent on the size and characteristics of the researchers' dataset. (Clark, Linzer, \& Methods, 2015). The table below gives the estimation results for both models. 
Table 5: Fixed and Random Effect estimation

\begin{tabular}{|l|l|l|}
\hline Variables & $\begin{array}{l}\text { Random Effects } \\
\text { Estimations }\end{array}$ & Fixed effects Estimations \\
\hline CAP & $-9.14 \mathrm{E}+08$ & $-4.13 \mathrm{E}+08$ \\
& $(2.12 \mathrm{E}+08)$ & $2.43 \mathrm{E}+08$ \\
& {$[-4.318138]^{* * *}$} & {$[-1.696991]^{*}$} \\
\hline COC & $5.62 \mathrm{E}+09$ & $1.39 \mathrm{E}+09$ \\
& $(6.53 \mathrm{E}+09)$ & $(8.78 \mathrm{E}+09)$ \\
& {$[0.860880]$} & {$[0.158239]$} \\
\hline HDI & $3.08 \mathrm{E}+10$ & $-1.67 \mathrm{E}+11$ \\
& $(4.92 \mathrm{E}+10)$ & $(7.79 \mathrm{E}+10)$ \\
& {$[0.626902]$} & {$[-2.145451]^{* *}$} \\
\hline INF & $2.34 \mathrm{E}+08$ & -44103661 \\
& $(59027780)$ & $(79532078)$ \\
& {$[3.963990]^{* * *}$} & {$[-0.554539]$} \\
\hline LAB & 7936.433 & 19489.24 \\
& $(346.5050)$ & $(1234.704)$ \\
& {$[22.90424]^{* * *}$} & {$[15.78454]^{* * *}$} \\
\hline TRADE & 76232994 & 36060160 \\
& $(58259872)$ & $(63089912)$ \\
& {$[1.308499]$} & {$[0.571568]$} \\
\hline \multirow{2}{*}{ CONS } & $-4.13 \mathrm{E}+10$ & $-1.83 \mathrm{E}+10$ \\
& $(2.08 \mathrm{E}+10)$ & $(2.92 \mathrm{E}+10)$ \\
\hline R-SQUARED & {$[-1.983735]$} & {$[-0.627107]$} \\
\hline ADJUSTED R- & 0.699495 & 0.948605 \\
\hline SQUARED & & \\
\hline PROB(F-STATISTIC) & 0.691481 & 0.943466 \\
\hline & 0.000000 & 0.000000 \\
\hline
\end{tabular}

NB: Values in( )is the Std. Errors and values in [ ] represents t. statistics. *** Significant at the $1 \%$ level, ** Significant at the 5\% level, * Significant at the 10\% level.

Source: Author Computation, 2019(Eviews9).

From the above results by using the Fixed effects model for estimation, the following observations can be made.It can be seen that the model has an $\mathrm{R}$ Squared and an Adjusted R Squared of 0.948605 and 0.943466 respectively, showing an explanation power of 0.949 indicating that the explanatory variables can explain to a maximum of $94 \%$ of the dependent variable in the situation under discussion, meanwhile there is a prob value of 0.0000 showing a significant model fitness.

It can be seen that Capital Formation has a significant impact on sustainable economic performance, in that when there are capital injections in the economy, there is going to be increased in the capacity of production. This result is consistent with Levine ((1992))in his study "A Sensitivity Analysis of Cross-Country Growth Regressions". 
AgainBlomstrom, Lipsey, and Zejan (1993); (Kendrick, 1993) also supported this result in that indeed capital formation helps in sustainable economic performance.

Control of Corruption catches perceptions of the degree to which public power is practiced for private gain, including both trivial and amazing types of corruption, just as "capture" of the state by elites and private interests. In this situation control of corruption as the variable of interest deals with how the government is able to tackle corruption and its related activity. It can be noted from the above result that the level of corruption is hindering sustainable economic performance in Africa, this is statistically proven that it's not significant and has no correlation on sustainable economic performance with a prob value of 0.8744 and a coefficient of $1.39 \mathrm{E}+09$. Mauro (1995) hypothesized that corruption has no significant impact on economic growth and confirms the result of this study. Blackburn et al. (2006) indicated that the association between corruption and development is projected to be negative. $\mathrm{Li}, \mathrm{Xu}$, Zou, and Politics (2000)also confirms these results in their study and recorded that corruption retards sustainable economic growth. Most researchers agreed that corruption leads to poor economic performance. The level of control of corruption will induce the rate of economic growth.

Most writers and studies have shown that human development is a catalyst to increase economic growth. The result of this proves that human development in Africa helps in increasing sustainable economic performance, the prob value shows a positive sign of sustainable economic performance at a significant level of $5 \%$. This result is confirmed in a study by (Gustav Ranis, 2004; Gustav Ranis, Stewart, \& Ramirez, 2000) who proved this result in their studies. Human development cannot be left out when policies and decisions on economic performance are made. African countries can much more increase the quality of their human development base when taken and implementing economic policies and decisions.

The reported results above indicate that inflation slows down growth among all things considered in the study. It can be noted inflation shows a negative and insignificant impact of sustainable economic performance in Africa, statistically, it can be seen a unit increase in the prices of goods and service leads to a reduction in growth and performance to about $100 \%$. Inflation has been a major macroeconomic issue in most African countries since there are always trade deficit and prices of goods are always determined by the exchange rate. This hypothesis is confirmed by (Barro, 1995; Gokal \& Hanif, 2004). Again Jones, Manuelli, and Control (1995) in his study confirmed that inflation has no positive effects on growth and performance.

From the above, it can be noted that labour has a positive significant and relation to economic performance. Technically serves as a spinal cord of every economy, from the above can be seen that a unit increase labor increases economic performance and also shows that labour is significant on economic performance at a significant level of $1 \%$. Kapsos (2005) and Khan (2007)indicated in their study "Growth, employment and poverty" and recorded that labour confirms the growth in economic growth. 
Most African countries face the problem of the trade deficit since most of the factors of production are imported from other countries which in turn increase the trade deficit. This situation is confirmed in this study and it is recorded that trade openness has no significant impact on economic performance. A study from (Brunner, 2003; Rodriguez \& Rodrik, 2000; Silajdzic \& Mehic, 2018)and Rigobon and Rodrik (2005)confirm this result in their studies, this result also contradicts a study by Koskei, Buigut, and Kibet (2013)and Grossman and Helpman (1991) who confirmed that trade openness has a positive influence on economic performance.

\subsection{Robustness check}

Cross-sectional dependence has to do with the effect of stuns in one nation on another nation when the two nations have a place in the panel data set. The study tested the cross-sectional dependence on the cross section variables. The result stated below in the table indicate that all the methodology used to estimate the cross-sectional dependence rejected the null hypothesis which stated there is no cross-sectional at $1 \%$ significance level.

Table 6: Results on Cross Section
Test
Statistic
d.f. $\quad$ Prob.

Breusch-Pagan LM

487.6913

120

0.0000

Pesaran scaled LM

22.70158

0.0000

Pesaran CD

Source: Author Computation, 2019(Eviews9)

\subsection{SUMMARY, RECOMMENDATIONS AND CONCLUSION}

The study examines corruption and its effects on achieving sustainable economic performance in Africa with a data set from 2002-2017. The Hausman Test for determining the appropriate model selection between Random and Fixed effects with the fixed effects model of estimation chosen to be the appropriate model of estimation indicating that the degree of relationship and significant between corruption and sustainable economic performance. The $\mathrm{R}^{2}$ explains that $95 \%$ of variations in sustainable economic performance in the estimation of prime independent variables. Aside corruption having a negative and insignificant impact on sustainable economic performance, an increase in human development and labour resulted in positive and significant relations on sustainable economic performance, with the rest of the explanatory variables having poor and negative affiliations with sustainable economic performance.

There is along these lines a solid recommendation and promotion for all-around audit of anticorruption offices business as usual, rejuvenation of residents through attitudinal re-introduction, economic expansion, and genuine federalism ought to hold onto as a key reasonable achievement of sustainable economic performance even with the current sectorial battle for growth and development which corruption has imprint after some 
time. The above recommendations notwithstanding, are sine qua non in the African nations setting if the vision 20:2020 must be acknowledged, which its prime target is to put Africa among the class of developed or quick developing economies by 20;2020 and similarly grasp the sustainable development goals SDG.

\section{REFERENCES}

[1]. Abed, M. G. T., \& Davoodi, M. H. R. (2000). Corruption, structural reforms, and economic performance in the transition economies: International Monetary Fund.

[2]. Alesina, A., \& Weder, B. J. A. E. R. (2002). Do corrupt governments receive less foreign aid? , 92(4), 1126-1137.

[3]. Bantekas, I. J. J. o. I. C. J. (2006). Corruption as an international crime and crime against humanity: An outline of supplementary criminal justice policies. 4(3), 466484.

[4]. Barro, R. J. (1995). Inflation and economic growth. Retrieved from

[5]. Blackburn, K., Bose, N., Haque, M. E. J. J. o. E. D., \& Control. (2006). The incidence and persistence of corruption in economic development. 30(12), 24472467.

[6]. Blomstrom, M., Lipsey, R. E., \& Zejan, M. (1993). Is fixed investment the key to economic growth?

[7]. Brunner, M. A. D. (2003). The long-run effects of trade on income and income growth: International Monetary Fund.

[8]. Campos, J. E., \& Pradhan, S. (2007). The many faces of corruption: tracking vulnerabilities at the sector level: The World Bank.

[9]. Clark, T. S., Linzer, D. A. J. P. S. R., \& Methods. (2015). Should I use fixed or random effects? , 3(2), 399-408.

[10]. Del Monte, A., \& Papagni, E. J. E. j. o. p. e. (2001). Public expenditure, corruption, and economic growth: the case of Italy. 17(1), 1-16.

[11]. Easterly, W. (2002). The elusive quest for growth: economists' adventures and misadventures in the tropics: MIT press.

[12]. Friedrich, C. J. (1972). The Pathology of Politics: violence, betrayal, corruption, secrecy, and propaganda: Harper \& Row New York.

[13]. Gokal, V., \& Hanif, S. (2004). Relationship between inflation and economic growth: Economics Department, Reserve Bank of Fiji.

[14]. Grossman, G. M., \& Helpman, E. J. E. e. r. (1991). Trade, knowledge spillovers, and growth. 35(2-3), 517-526.

[15]. Habib, M., \& Zurawicki, L. J. I. B. R. (2001). Country-level investments and the effect of corruption-some empirical evidence. 10(6), 687-700.

[16]. Huntington, S. (1968). Political order in changing societies New Haven: Yale U. In Press.

[17]. Jones, L. E., Manuelli, R. E. J. J. o. E. D., \& Control. (1995). Growth and the effects of inflation. 19(8), 1405-1428.

[18]. Kapsos, S. (2005). Employment Intensity of Growth: The. Trends and Macroeconomic Determinants. Employment Strategy Papers 2005/12. Trends and Macroeconomic Determinants. Employment Strategy Papers 2005/12: International Labour Organization.

[19]. Kendrick, J. W. J. C. t. e. a. (1993). How much does capital explain? , 214, 129129.

[20]. Khan, A. R. (2007). Growth, employment, and poverty: An analysis of the vital nexus based on some recent UNDP and ILO/SIDA studies: UN. 
[21]. Koskei, N. S. I., Buigut, K., \& Kibet, J. (2013). Impact of openness, foreign direct investment, gross capital formation on economic growth in Kenya.

[22]. Lash, N. A., \& Batavia, B. J. T. J. o. D. A. (2013). Government economic intervention and corruption. 1-15.

[23]. Leff, N. H. J. A. b. s. (1964). Economic development through bureaucratic corruption. 8(3), 8-14.

[24]. Levine, R. R., David. ((1992)). A Sensitivity Analysis of Cross-Country Growth Regressions. American Economic Review.

[25]. Li, H., Xu, L. C., Zou, H. f. J. E., \& Politics. (2000). Corruption, income distribution, and growth. 12(2), 155-182.

[26]. Lumumba, P. J. C. i. A. a. t. t. j., \& net, s. p. G. G. (2014). Corruption: the bane of Africa.

[27]. Mauro, P. J. T. q. j. o. e. (1995). Corruption and growth. 110(3), 681-712.

[28]. Menocal, R. A., Taxell, N., Johnsøn, J., Schmaljohann, M., Montero, A., \& De Simone, F. J. E. P. o. C., Department for International Development. (2015). Why Corruption Matters: Understanding Causes, Effects and How to Address Them.

[29]. Mo, P. H. J. J. o. c. e. (2001). Corruption and economic growth. 29(1), 66-79.

[30]. Molyneux, D. H., Hotez, P. J., \& Fenwick, A. J. P. m. (2005). "Rapid-impact interventions": how a policy of integrated control for Africa's neglected tropical diseases could benefit the poor. 2(11), e336.

[31]. MUKANDALA, R., FOX, L., \& LIEBENTHAL, R. J. A. A. s. P. (2006). The Political Economy of Pro-Poor Policies in Africa. 1.

[32]. Nye, J. S. J. A. p. s. r. (1967). Corruption and political development: A costbenefit analysis. $61(2), 417-427$.

[33]. Pearson, K. J. P. o. t. R. S. o. L. (1895). Note on regression and inheritance in the case of two parents. 58, 240-242.

[34]. Ranis, G. (2004). Human development and economic growth. (887).

[35]. Ranis, G., Stewart, F., \& Ramirez, A. J. W. d. (2000). Economic growth and human development. 28(2), 197-219.

[36]. Rigobon, R., \& Rodrik, D. J. E. o. t. (2005). Rule of law, democracy, openness, and income: Estimating the interrelationships1. 13(3), 533-564.

[37]. Rodriguez, F., \& Rodrik, D. J. N. m. a. (2000). Trade policy and economic growth: a skeptic's guide to the cross-national evidence. 15, 261-325.

[38]. Rwekaza, M. J. H., AAPS, Books, Zimbabwe. (2000). African Public Administration: A reader.

[39]. Silajdzic, S., \& Mehic, E. (2018). Trade Openness and Economic Growth: Empirical Evidence from Transition Economies. In Trade and Global Market: IntechOpen.

[40]. Tanzi, V., \& Davoodi, H. (1998). Corruption, public investment, and growth. In The welfare state, public investment, and growth (pp. 41-60): Springer.

[41]. Vinod, H. D. J. J. o. A. E. (1999). Statistical analysis of corruption data and using the Internet to reduce corruption. 10(4), 591-603. 